\title{
Analysis of Meningitis Cases in Pediatric Intensive Care Unit: 8-Year Single Center Experience
}

\author{
Çocuk Yoğun Bakım Ünitesinde Menenjit Olgularının Analizi: \\ 8 Yıllık Tek Merkez Deneyimi
}

\author{
Burcu Bursal Duramaz ${ }^{1 \oplus}$, Hasan Serdar Kıhtır ${ }^{2}$, Mey Talip Petmezci ${ }^{2}$, Osman Yeşilbaşి \\ Nermin Ankay ${ }^{3} \oplus$, Nevin Hatipoğlu ${ }^{4 \oplus}$, Esra Şevketoğlu ${ }^{2 \oplus}$ \\ ${ }^{1}$ Department of Pediatric Infectious Diseases, Bezmiâlem Vakıf University Faculty of Medicine, Istanbul, Turkey \\ ${ }^{2}$ Department of Pediatric Intensive Care, Bakırköy Dr Sadi Konuk Training and Research Hospital, Istanbul, Turkey \\ ${ }^{3}$ Department of Pediatrics, Bakirkoy Dr Sadi Konuk Training and Research Hospital, Istanbul, Turkey \\ ${ }^{4}$ Department of Pediatric Infectious Diseases, Bakirkoy Dr Sadi Konuk Training and Research Hospital, Istanbul, Turkey
}

Received: 13 February 2020 / Accepted: 20 February 2020 / Publication date: 26 March 2020

Cite as: Bursal Duramaz B, Kıhtır HS, Petmezci MT, Yeşilbaş O, Ankay N, Hatipoğlu N, Şevketoğlu E. Analysis of meningitis cases in pediatric intensive care unit: 8-year single center experience. Med J Bakirkoy 2020;16(1):26-32.

\section{ABSTRACT}

Objective: The aim of the study was to evaluate clinical features, management of intensive care treatment, complications and mortality in children with meningitis treated in pediatric intensive care unit.

Method: Data of 47 patients who were followed-up in the pediatric intensive care unit between January 2006 and December 2014 with the diagnosis of meningitis were retrospectively reviewed. Patients were screened for demographic features, etiological and predisposing factors, physical examination and laboratory findings, treatment, prognosis, mortality rate, acute and chronic complications, Glasgow coma scale and pediatric mortality risk score.

Results: The age, sex distribution, hospitalization day, and chronic disease rate of aseptic meningitis and bacterial meningitis did not differ significantly. In bacterial meningitis, S. pneumoniae was detected in $12.5 \%$ of patients and N. meningitidis in $6.2 \%$ of patients. In aseptic meningitis, invasive ventilation, inotropic use rate and pediatric mortality risk score score were significantly lower than the bacterial meningitis ( $p=0.011, p=0.042$ and $p=0.043$, respectively).

Conclusion: Early diagnosis, initiation of appropriate antibiotic therapy, and provision of necessary life support in life-threatening complications may reduce the need for pediatric intensive care unit, morbidity and mortality in meningitis patients. We believe that multicenter and prospective studies are needed to reduce sequelae and mortality of meningitis cases observed in pediatric intensive care unit.

Keywords: bacterial meningitis, aseptic meningitis, mortality, pediatric intensive care unit

öz

Amaç: Bu çalışmada çocuk yoğun bakım ünitesinde tedavi edilen menenjit tanısı almış çocuk hastaların klinik özelliklerinin, yoğun bakım tedavi yönetiminin, komplikasyonların ve mortalitenin değerlendirilmesi amaçlandı.

Yöntem: Çocuk yoğun bakım ünitesinde Ocak 2006 ile Aralık 2014 tarihleri arasında menenjit tanısı ile takip edilen 47 hastaya ait veriler geriye dönük olarak incelendi. Hastalar demografik özellikler, etiyolojik ve hazırlayıcı faktörler, fizik muayene ve laboratuvar bulguları, uygulanan tedavi, prognoz, mortalite oranı, akut ve kronik komplikasyonlar, Glaskow koma skalası ve pediatrik mortalite riski skorlaması açısından tarandı. Bulgular: Aseptik menenjit ve bakteriyel menenjit grubunda hastaların yaşları, cinsiyet dağılımı, yatış günü, kronik hastalık oranı anlamlı farklıık göstermedi. Bakteriyel menenjitte, hastaların \%12,5'inde S. pneumoniae ve \%6,2'sinde N. meningitidis saptandı. Aseptik menenjit grubunda invazif ventilasyon, inotrop kullanım oranı ve pediatrik mortalite riski puanı bakteriyel menenjit grubundan anlamlı olarak daha düşüktü (sırasıyla $p=0.011, p=0.042$ ve $p=0.043$ ).

Sonuç: Erken tanı, uygun antibiyotik tedavisinin başlanması ve hayatı tehdit eden komplikasyonlarda gerekli yaşam desteğinin sağlanması menenjitli hastalarda çocuk yoğun bakım ünitesi ihtiyacını, morbidite ve mortaliteyi azaltır. Ózellikle çocuk yoğun bakım ünitesinde izlenen menenjit olgularının sekel ve mortalitesinin azaltılmasına ışık tutacak çok merkezli, daha fazla sayıda hasta içeren ve prospektif tasarımlı çalışmalara ihtiyaç olduğu kanısındayız.

Anahtar kelimeler: anatomi, vagus siniri, karotis arter, endarterektomi, kadavra çalışması

Corresponding Author:

burcubursal@hotmail.com
B. Bursal Duramaz 0000-0002-4098-947X H. S. Kıhtir 0000-0003-0120-8711 M. T. Petmezci 0000-0002-6409-3854 O. Yeşilbaş 0000-0002-4290-0491

N. Ankay 0000-0003-4642-221X

N. Hatipoğlu 0000-0003-2858-0150 E. Şevketoğlu 0000-0002-8330-2877

(c) Telif hakkı Sağlık Bilimleri Üniversitesi Bakırköy Dr. Sadi Konuk Eğitim ve Araştırma Hastanesi'ne aittir. Logos Tıp Yayıncılık tarafindan yayınlanmaktadır. Bu dergide yayınlanan bütün makaleler Creative Commons Atff-GayriTicari 4.0 Uluslararası Lisansı ile lisanslanmıştır.

(c) Copyright Health Sciences University Bakırköy Sadi Konuk Training and Research Hospital. This journal published by Logos Medical Publishing.

Licenced by Creative Commons Attribution-NonCommercial 4.0 International (CC BY-NC 4.0) 


\section{INTRODUCTION}

Meningitis is an acute or chronic inflammatory disease caused by various microorganisms, and involving the pia and arachnoid membranes surrounding the brain and spinal cord. The disease is characterized by cellular and biochemical changes in the cerebrospinal fluid (CSF) and neurological findings as clinical manifestations. The fetiologic actors that cause meningitis can be bacteria, viruses, fungi or parasites (1). Neisseria meningitidis, Streptococcus pneumoniae and Haemophilus influenzae type b were found to be the most common agents of acute bacterial meningitis in our country ${ }^{(2)}$. Bacterial meningitis is less frequently seen thanks to routine vaccination programs against $S$. pneumoniae and H.influenzae type $B$ and the introduction of conjugated meningococcal vaccines. Aseptic meningitis is more common in childhood and viruses are mostly responsible for etiology (3). In $50-80 \%$ of cases with aseptic meningitis, enteroviruses have been reported as causative agents.

Other viral agents include viruses such as herpes simplex virus, Ebstein-Barr virus, varicella zoster virus, cytomegalovirus, adenovirus, rubella, mumps virus, and measles virus ${ }^{(4)}$. Diseases that cause aseptic meningitis include tuberculosis, leptospirosis, ricketsia and brucellosis ${ }^{\left({ }^{3}\right)}$. Meningitis continues to be an important health problem due to death or sequelae in children. In order to reduce the development of complications in these patients, early diagnosis and effective treatment should be initiated without wasting time ${ }^{(5)}$. Neurological or hemodynamic deterioration caused by meningitis requires close follow-up of patients in the pediatric intensive care units (PICUs) in terms of the cardiorespiratory system disorders ${ }^{(6)}$. Most of the deaths in the hospital due to meningitis occur within the first 48 hours in the PICU ${ }^{(7)}$. In our study, we aimed to evaluate the clinical features, management of intensive care treatment, complications and mortality of the patients with meningitis in pediatric patient cohort treated in PICU.

\section{MATERIAL and METHODS}

This study was conducted in accordance with the principles of Helsinki Declaration after receiving the approval of the institutional ethics committee (ethics committee research approval number and date of decision: 2015/50 - 2015/05/08), in a nine-bed highly -advanced PICU with bedside echocardiography, plasmapheresis, hemodiafiltration. Nine mechanical ventilation facilities. The data of 47 patients who were followed-up with the diagnosis of meningitis between January 2006 and December 2014 were analyzed retrospectively. The patients were evaluated in two groups as acute bacterial meningitis and aseptic meningitis. The files were scanned in terms of demographic characteristics, etiological and predisposing factors, physical examination and laboratory findings, treatment, prognosis, mortality rates, acute and chronic complications, Glaskow coma scale (GCS) and Pediatric Risk of Mortality (PRISM) scores. Diagnosis of cases with acute bacterial meningitis was made based on cerebrospinal fluid (CSF) findings (turbid appearance, protein $>100 \mathrm{mg} /$ $\mathrm{dL}$, CSF glucose $<40 \mathrm{mg} / \mathrm{dL}$, high leukocyte count, and polymorphonuclear leukocytes $>75 \%$ ) and / or isolation of the pathogenic factor in culture. The diagnosis of tuberculous meningitis was made based on the clinical course of subacute onset, the detection of $100-500 / \mathrm{mm}^{3}$ cells in CSF (lymphocyte dominancy), increased protein levels in CSF, and acid-fast bacilli (AFB) in CSF and fasting gastric juice, growth of Mycobacterium tuberculosis in CSF culture or the presence of basal arachnoiditis and tuberculoma as shown radiologically by magnetic resonance imaging (MRI). Patients meeting any one and several of these criteria were evaluated as tuberculous meningitis. ${ }^{(8)}$. The diagnosis of aseptic meningitis was made when the WBC counts in CSF were above $100-500 / \mathrm{mm}^{3}$ with lymphocytic dominancy, the CSF protein at normal or close to normal levels, and the CSF glucose levels close to half or above of the blood glucose levels measured simultaneously ${ }^{(8)}$.

Average, standard deviation, median, maximum, minimum, frequency and ratio values were used in the descriptive statistics of data. The distribution of variables was checked with Kolmogorov-Smirnov test. Independent sample- $t$ test and Mann-Whitney $U$ test were used in the analysis of quantitative data. In the analysis of qualitative data, chi-square test and when chi-square conditions were not met Fisher test were used. Statistical Package for Social Sciences "version 22.0 (IBM Corp., Armonk, NY, USA) program was used in the analysis. 
Table 1. Demographic and clinical features of patients.

\begin{tabular}{|c|c|c|c|c|c|c|}
\hline & \multicolumn{2}{|c|}{ RA patients $(n=50)$} & \multicolumn{2}{|c|}{ Bacterial Meningitis } & \multirow[b]{2}{*}{$\mathbf{p}$} & \multirow[b]{2}{*}{ m } \\
\hline & Mean $\pm S D$ / N (\%) & Median & Mean \pm SD / N (\%) & Median & & \\
\hline Age & $5,9 \pm 4,1$ & 5,4 & $4,5 \pm 4,3$ & 2,6 & $\begin{array}{l}0,153 \\
0,012\end{array}$ & $x^{2}$ \\
\hline \multicolumn{7}{|l|}{ Gender } \\
\hline Male & $6(27,3 \%)$ & & $16(64,0 \%)$ & & 0,513 & $\mathrm{~m}$ \\
\hline Female & $16(72,7 \%)$ & & $9(36,0 \%)$ & & & \\
\hline Hospitalization (days) & $14,3 \pm 15,9$ & 10,5 & $10,0 \pm 10,8$ & 5,0 & 0,939 & $\mathrm{~m}$ \\
\hline PRISM score & $10,9 \pm 11,1$ & 6,0 & $9,5 \pm 10,7$ & 6,0 & 0,673 & $\mathrm{~m}$ \\
\hline GCS & $10,5 \pm 3,1$ & 11,0 & $10,6 \pm 3,4$ & 10,0 & 0,654 & $x^{2}$ \\
\hline Chronic disease & $4(18,2 \%)$ & & $7(28 \%)$ & & & \\
\hline
\end{tabular}

m: Mann-Whitney $U$ test, $X^{2}$ : Chi-square test (Fischer test)

GcS: Glaskow coma score, PRISM: Pediatric risk of mortality

Table 2. Evaluation of clinical and laboratory findings of patients.

\begin{tabular}{|c|c|c|c|c|c|}
\hline \multirow[b]{2}{*}{ Symptoms and findings } & \multicolumn{2}{|c|}{ Aseptic Meningitis } & \multicolumn{2}{|c|}{ Bacterial Meningitis } & \multirow[b]{2}{*}{$\mathbf{p}$} \\
\hline & Mean $\pm S D$ / N (\%) & Median & Mean士SD / N (\%) & Median & \\
\hline Fire & $17(77,3 \%)$ & & $24(96,0 \%)$ & & $0,055 X^{2}$ \\
\hline Headache & $9(40,9 \%)$ & & $11(44,0 \%)$ & & $0,831 X^{2}$ \\
\hline Vomiting & $11(50,0 \%)$ & & $17(68,0 \%)$ & & $0,210 x^{2}$ \\
\hline Fontanel bulge & $3(13,6 \%)$ & & $7(28,0 \%)$ & & $0,230 x^{2}$ \\
\hline Debris & $1(4,5 \%)$ & & $8(32,0 \%)$ & & $0,017 X^{2}$ \\
\hline Blurring of Consciousness & $12(54,5 \%)$ & & $6(24,0 \%)$ & & $0,032 X^{2}$ \\
\hline Convsulsion & $10(45,5 \%)$ & & $4(16,0 \%)$ & & $0,028 X^{2}$ \\
\hline Diarrhea & $2(9,1 \%)$ & & $4(16,0 \%)$ & & $0,479 x^{2}$ \\
\hline Acute Respiratory Failure & $1(4,5 \%)$ & & $1(4,0 \%)$ & & $1,000 x^{2}$ \\
\hline Nape Hardness & $11(50,0 \%)$ & & $12(48,0 \%)$ & & $0,891 X^{2}$ \\
\hline Kernig positivity & $4(18,2 \%)$ & & $6(24,0 \%)$ & & $0,627 X^{2}$ \\
\hline Brudzinski positivity & $1(4,5 \%)$ & & $3(12,0 \%)$ & & $0,611 x^{2}$ \\
\hline Antibiotic usage & $11(50,0 \%)$ & & $10(40,0 \%)$ & & $0,491 X^{2}$ \\
\hline \multicolumn{6}{|l|}{ Blood findings } \\
\hline White blood cell (WBC) & $14,0 \pm 8,2$ & 13,0 & $21,2 \pm 12,2$ & 22,0 & $0,017 \mathrm{~m}$ \\
\hline C-reactive protein & $8,6 \pm 7,0$ & 6,5 & $14,6 \pm 8,5$ & 12,0 & $0,008 \mathrm{~m}$ \\
\hline Neutrophil (NEU \#) & $72,5 \pm 18,1$ & 77,0 & $74,9 \pm 18,6$ & 84,0 & $0,353 \mathrm{~m}$ \\
\hline Lymphocyte (LYM \#) & $17,8 \pm 13,8$ & 16,0 & $17,2 \pm 16,5$ & 9,0 & $0,455 \mathrm{~m}$ \\
\hline
\end{tabular}

m: Mann-Whitney $U$ test, $X^{2}$ : Chi-square test (Fischer test)

\section{RESULTS}

The demographic and clinical features of the patients are given in Table 1. A total of 47 patients were included in our study (M/F: 22/25). In the aseptic meningitis and bacterial meningitis groups, the age, days of hospitalization and rate of chronic disease did not differ significantly between groups. There was no significant difference in GKS value, fever, headache, vomiting, fontanel swelling, rash, confusion, convulsion, diarrhea, acute respiratory distress, neck stiffness ratio, Kernig and Brudzinski test positivity, and empirical antibiotic use among the groups. In addition, WBC counts, neutrophils, lymphocytes did not differ significantly between the groups. While the CRP value and CSF protein were significantly lower in the aseptic meningitis group than in the bacterial meningitis group, the percentage of lymphocytes was significantly higher $(p=0.008$; $p=0.012$ and $p=0.000$, respectively).

In the bacterial meningitis group, while the CSF glucose and CSF glucose / blood glucose were lower than the aseptic meningitis group, the percentage of polymorphonuclear leukocytes was significantly higher $(p<0.001, p<0.001$ and $p<0.001$, respectively) 
Table 3. Evaluation of the treatment methods of patients.

\begin{tabular}{|c|c|c|c|c|c|}
\hline \multirow[b]{2}{*}{ Need for steroids } & \multicolumn{2}{|c|}{ Aseptic Meningitis } & \multicolumn{2}{|c|}{ Bacterial Meningitis } & \multirow[b]{2}{*}{$\mathbf{P}$} \\
\hline & $\mathbf{N}$ & $\%$ & $\mathbf{N}$ & $\%$ & \\
\hline Dexamethasone & 10 & $45,5 \%$ & 12 & $48,0 \%$ & $0,861 X^{2}$ \\
\hline \multicolumn{6}{|c|}{ Need for respiratory support } \\
\hline Invasive ventilation & 6 & $27,3 \%$ & 9 & $36,0 \%$ & $0,522 x^{2}$ \\
\hline CVS Inotrop & 5 & $22,7 \%$ & 7 & $28,0 \%$ & $0,679 x^{2}$ \\
\hline
\end{tabular}

$X^{2}$ : Chi-square test (Fischer test)

CVS: cardiovascular system

Table 4. Comparison of the groups in terms of complication and prognosis.

\begin{tabular}{|c|c|c|c|c|c|}
\hline \multirow[b]{2}{*}{ Acute Complication } & \multicolumn{2}{|c|}{ Aseptic Meningitis } & \multicolumn{2}{|c|}{ Bacterial Meningitis } & \multirow[b]{2}{*}{$\mathbf{P}$} \\
\hline & $\mathbf{N}$ & $\%$ & $\mathbf{N}$ & $\%$ & \\
\hline Hydrocephalus & 2 & $9,1 \%$ & 1 & $4,0 \%$ & $0,593 X^{2}$ \\
\hline Convulsion & 2 & $9,1 \%$ & 3 & $12,0 \%$ & $0,747 X^{2}$ \\
\hline Abscess & 1 & $4,5 \%$ & 1 & $4,0 \%$ & $1,000 X^{2}$ \\
\hline Diabetes insipitus (DI) & 6 & $27,3 \%$ & 1 & $4,0 \%$ & $0,025 x^{2}$ \\
\hline \multicolumn{6}{|l|}{ Prognosis } \\
\hline Neuromotor disorders & 1 & $4,5 \%$ & 4 & $16,0 \%$ & $0,204 X^{2}$ \\
\hline Failure of breath & 1 & $4,5 \%$ & 1 & $4,0 \%$ & $1,000 X^{2}$ \\
\hline Death & 4 & $18,2 \%$ & 1 & $4,0 \%$ & $0,116 X^{2}$ \\
\hline Full recovery & 15 & $68,2 \%$ & 18 & $72,0 \%$ & $0,775 x^{2}$ \\
\hline
\end{tabular}

$X^{2}$ : Chi-square test (Fischer test)

(Table 2). In the groups, ophthalmoscopic findings of the fundus, computed tomography (CT) and magnetic resonance imaging (MRI) findings obtained before lumbar puncture (LP) were comparable between groups. In bacterial meningitis, $S$. pneumoniae was determined as the causative agent in $7(28 \%)$ patients (growth in both blood and CSF cultures in three, and only in CSF culture in one patient), while in 5 (20\%) patients, $N$. meningitidis was grown both in blood and CSF cultures. In 7 (31.8\%) patients with aseptic meningitis, $M$. tuberculosis was considered as the causative agent, but only in two patients it was isolated in fasting gastric juice. There was no growth in blood and CSF cultures of patients who were followed up with tuberculous meningitis. Steroid use and oxygen utilization rates did not differ between groups. Noninvasive ventilation was not used in both groups. Invasive ventilation and frequency of inotrop use and PRISM scores in the aseptic meningitis group did not differ when compared with the bacterial meningitis group $(p=0.522, p=0.667$ and $p=0.939$, respectively). Continuous renal replacement therapy (DRRT) and plasma exchange rates were similar between groups (Table 3 ). Any significant difference was not observed between the groups in terms of acute complications and prognosis. All of five exited patients received the diagnosis of bacterial meningitis (Table 4).

\section{DISCUSSION}

Acute meningitis is one of the most serious infections in children. The main goal in acute bacterial meningitis is to establish diagnosis at an early stage, and to start effective treatment without wasting time to prevent complications ${ }^{(9)}$. Acute meningitis has a high risk of acute complications, mortality and long-term morbidity. In the studies performed, mean ages at the time of diagnosis of acute bacterial meningitis were found to be $4.8 \pm 4.1$ years by Ceyhan et al. ${ }^{(10)}$ and 3.4 years by Mongelluzo et al. ${ }^{(11)}$. In our study mean ages at diagnosis in acute bacterial, and 
aseptic meningitis were $4.5 \pm 4.3$, and $5.9 \pm 4.1$ years, in accordance with the literature, respectively. In previous studies it has been reported that central nervous system infections are more common in men. Michos et al. ${ }^{(13)}$ reported $\mathrm{M} / \mathrm{F}$ ratio in bacterial meningitis as 1.79 , while Harald et al ${ }^{(14)}$ found the $\mathrm{M} / \mathrm{F}$ ratios as 1.33 in bacterial, and 1.84 in aseptic meningitis and in aseptic meningitis, respectively Şensoy et al. ${ }^{(12)}$, and Ceyhan et al. ${ }^{(10)}$ from our country reported $M / F$ ratios as 2.05 , and 1.55 in aseptic meningitis, respectively. In our study, the $\mathrm{M} / \mathrm{F}$ ratio was 1.78 in bacterial, and 0.37 , in aseptic meningitis. Our results in bacterial meningitis are consistent with the literature, while in aseptic meningitis, male patients needed intensive care treatment less than girls.

In many cases, it is difficult to differentiate between bacterial and aseptic meningitis. Accurate diagnosis cannot be made in all patients by analyzing peripheral blood and CSF (such as CSF culture, blood culture, Gram staining, PCR, latex agglutination) ${ }^{(14)}$. Therefore, many researchers have developed a bacterial meningitis scoring (BMS) system ${ }^{(15,16)}$. If peripheral blood CRP level was $<2 \mathrm{mg} / \mathrm{dL}$ Harald et al. used BMS in favor of aseptic meningitis, and if CSF protein level was $>100 \mathrm{mg} / \mathrm{dL}$ then they used BMS in favor of bacterial meningitis. If glucose levels in CSF were $<53$ $\mathrm{mg} / \mathrm{dL}$, they used BMS scale scores in favour of bacterial meningitis. As a result using BMS system they differentiated 54 of 71 patients with viral meningitis from bacterial meningitis ${ }^{(14)}$. In our study, 25 (53.2\%) patients were diagnosed with bacterial meningitis and $22(46.8 \%)$ patients with viral meningitis based on clinical findings, CSF examinations, biochemical tests, CSF, and blood cultures. In our study, CRP $<2$ $\mathrm{mg} / \mathrm{dL}$ was detected in only three patients who were followed up due to aseptic meningitis. Based on this data, since the CRP value is increased in bacterial and aseptic meningitis it was shown that the CRP value alone cannot be used for the differentiation between both groups. In our study, in $44 \%$ of patients with purulent meningitis, there was a history of empirical antibiotic use, and only in six (24\%) of 25 patients bacterial growth was detected in CSF cultures. Harald et al. found bacterial growth in CSF cultures in $14(66.6 \%)$ of 21 bacterial meningitis patients (14). Ceyhan et al, observed bacterial growth in CSF culture of $41(17 \%)$ out of 243 bacterial meningitis patients ${ }^{(10)}$. The vaccination of our patients in whom S. pneumoniae was detected as the causative pathogen was performed with 13- serotype conjugated pneumococcal vaccine (CPV) in accordance with the Ministry of Health vaccination schedule. Identification of serotypes of pneumococcal isolates is significant in terms of determining the vaccine serotypes. Surveillance studies in the pediatric age group are also important to establish the correct vaccine serotype repertoire. Therefore, we believe that the CPV content should be updated based on the results of pneumococcal serotype surveillance studies.

Acute bacterial meningitis is also an important cause of death and neurological sequela in children in our country. Early diagnosis and appropriate antibiotic selection are the most important steps of treatment. In a previous study, the rate of acute complications due to meningitis was found to be $16 \%{ }^{(17)}$. In our study, acute complications developed in $44 \%$ of children diagnosed with acute meningitis. This higher rate can be explained by frequent monitorization of thigh risk patients in PICU. Experiencing a convulsive attack in the acute phase of acute bacterial meningitis increases morbidity and mortality ${ }^{(18)}$. On the other hand, it has been shown that seizures seen at first admission or appear within the first four days do not have prognostic significance ${ }^{(19)}$. In our study, convulsion was the most frequently detected acute complication. Studies have shown that in acute bacterial meningitis and tuberculous meningitis, corticosteroid treatment performed half an hour before and four days after antibiotherapy reduces mortality, neurological sequelae and hearing loss in the long run ${ }^{(20,21)}$. In our study, 23 patients received corticosteroid therapy. The use of steroids in bacterial meningitis has become controversial in the literature over time. For this reason, a standard protocol regarding steroid use was not applied in our study. None of the patients had hearing loss, but one patient had vision loss, three patients had epilepsy, and five patients had neuromotor impairment. Taşkesen et al. reported the average length of hospital stay as $\mathbf{1 0 . 5}$ days ${ }^{(22)}$. Michos et al. ${ }^{(13)}$ indicated the average length of hospitalization for aseptic meningitis as four days, Şensoy et al. ${ }^{(12)}$ stated the average length of hospital stay as 6.2 days for aseptic meningitis. Although there is no statistical difference between the groups in terms of length of hospital stay, it is noteworthy 
that the duration of hospitalization of patients with bacterial meningitis (average 10 days) was shorter than that of patients with aseptic meningitis (average 14.3 days).

PRISM III is a scoring system in which intensive care patients are evaluated in terms of mortality. The high score is related to the mortality and morbidity rate in patients. In our study, the mean PRISM score was 9.5 in patients with bacterial meningitis and 10.9 in aseptic meningitis. Invasive device (CCRT, plasmapheresis) was used more frequently in patients with bacterial meningitis than patients with aseptic meningitis. The mortality rates range from $1.4 \%$ to $47 \%$ in different series ${ }^{(5,23,24)}$. An average mortality rate of $4.5 \%$ has been reported in developed countries ${ }^{25)}$. Our mortality rate was $10.6 \%$ and it was thought that the causative factor might be M. tuberculosis in four patients and S. pneumoniae was detected in one patient. While the pathogen was isolated in fasting gastric juice in two patients which thought to be the cause of $M$. tuberculosis, and the clinical findings and CSF analysis of the other two patients were compatible with M. tuberculosis meningitis. In a retrospective cohort study conducted in PICU, Folafoluwa et al. found the mortality rate as 7 percent. Abuhandan et al. found that the mortality rate was $2.2 \%$ in meningitis patients followed up in the pediatric service ${ }^{(26)}$. Wasier et al. found mortality rate as $49 \%$, and sequelae $48 \%$ of 49 patients with pneumococcal meningitis (27). In our study, three patients whose general condition was very poor at the time of admission were lost as a result of brain edema and two patients died of cerebral abscess. In our study, the reason for the high mortality rate compared to developed countries can be explained by the fact that the patients with high risk and low GKS scores are being hospitalized in our PICU, the delayed diagnosis and inadequate selection of initial treatment before hospitalization of the patients in the intensive care unit. In our study, any relationship was not found between age, gender, length of PICU stay, fever, meningial findings, CSF cell count, protein height, and complication(s). In their study Singhi et al., could not find a correlation between these factors and prognosis ${ }^{(7)}$. In our study, it was found that most of the deaths of inpatients due to meningitis occurred within the first 24-48 hours of PICU hospitalization.

\section{Limitations of the study}

The limitations of our study are its retrospective design, the absence of randomization and the small number of cases. On the other hand, to our knowledge, being one of the limited number of retrospective meningitis studies in PICU is the strength of our study.

\section{CONCLUSION}

Early diagnosis, initiation of appropriate antibiotic therapy and providing necessary life support in lifethreatening complications may reduce the need for PICU stay, morbidity and mortality in patients with meningitis. In cases that should be followed in PICU, rapid and multidisciplinary approach by ICU of infectious diseases and pediatric intensive care are essential for the management of possible acute and chronic complications. We believe that there is a need for prospectively designed multicentre studies performed with greater number of patients that will shed light on the reduction of sequelae and mortality of meningitis cases, especially in PICU.

Ethics Committee Approval: Bakırköy Dr. Approval was obtained from the Sadi Konuk Training and Research Hospital, Clinical Research Ethics Committee (2015/50, 2015/05/08).

Conflict of Interest: No potential conflict of interest relevant to this article was reported.

Funding: None

Informed Consent: Obtained

\section{REFERENCES}

1. Karakartal G, Altay G, Arısoy ES, ve ark. Menenjitler. Topçu A, Söyletir G, Doğanay $M$, editörler. İnfeksiyon Hastalıkları ve Mikrobiyolojisi. İstanbul: Nobel Tıp Kitabevi; 2002. p. 9851018.

2. Özdemir H, Tapısız A, Çiftçi E, ve ark. Menenjit tanısı ile izlenen hastalarımızın değerlendirilmesi. Çocuk Enf Derg. 2009;3(1):131-52.

3. Acar M, Sütçü M, Somer A. Çocuklarda Menenjite Güncel Yaklaşım. J Child 2014;14(3):95-9. https://doi.org/10.5222/j.child.2013.095

4. David R Chadwick. Viral Meningitis. Br Med Bull. 2005;76:114. https://doi.org/10.1093/bmb/ldh057

5. Kanra G, Ceyhan M, Kara A. Menenjit II: Klinik bulgular ve tanı. Çocuk Sağlığı ve Hastalıkları Dergisi 2003;46(2):128-38.

6. Rivers E, Nguyen B, Havstad S, et al. Early goal-directed therapy in the treatment of severe sepsis and septic shock. $\mathrm{N}$ Engl J Med. 2001;345(19):1368-77. https://doi.org/10.1056/NEJMoa010307

7. Singhi $S$, Singhi $P$, Baranwal A. Bacterial meningitis in children: 
critical care needs. Indian J Pediatr 2001:68:737-47. https://doi.org/10.1007/BF03191900

8. Charles GP. Cerebrospinal Fluid Findings in Central Nervous System Disorders. In: Kliegman RM, Behrman RE, Stanton BF, Schor NF, editors. Nelson textbook of pediatrics. 19th ed. Philadelphia: Elsevier Saunders; 2011. p. 2088.

9. Tunkel AR, Scheld WM. Acute meningitis. In: Mandell GL, Douglas RG, Bennett JE, eds. Mandell, Douglas and Bennett's Principles and Practice of Infectious Diseases. Sixth ed. New York: Churchill Livingstone; 2005. p. 1083-126.

10. Ceyhan M, Yıldırım I, Balmer P, et al. A prospective study of etiology of childhood acute bacterial meningitis, Turkey. Emerg Infect Dis. 2008;14(7):1089-96. https://doi.org/10.3201/eid1407.070938

11. Mongelluzzo J, Mohamad Z, Ten Have TR, et al. Corticosteroids and mortality in children with bacterial meningitis. JAMA 2008;299:2048-55. https://doi.org/10.1001/jama.299.17.2048

12. Şensoy G, Sel K, Özkaya E, et al. Enteroviral meningitis in children in Turkey. Cent Eur J Med. 2009;4(2):253-8. https://doi.org/10.2478/s11536-008-0055-5

13. Michos AG, Syriopoulou VP, Hadjichristodoulou C, et al Aseptic meningitis in children: analysis of 506 cases. PLoS ONE 2007;2(7):1-6. https://doi.org/10.1371/journal.pone.0000674

14. Harald GC, Lieve E, Johan $\mathrm{H}$, et al. Differential diagnosis between viral and bacterial meningitis in children. Eur J Emerg Med. 2007;14(6):343-7. https://doi.org/10.1097/MEJ.0b013e328270366b

15. Dubos F, Moulin F, Gajdos V. Serum procalcitonin and other biologic markers to distinguish between bacterial and aseptic meningitis. J Pediatr. 2006;149:72-6. https://doi.org/10.1016/j.jpeds.2006.02.034

16. Nigrovic E, Kuppermann N, Macias C, et al. Clinical prediction rule for identifying children with cerebrospinal fluid pleocytosis at very low risk of bacterial meningitis. JAMA 2007;297:5260 .

https://doi.org/10.1001/jama.297.1.52

17. Rieds Fx, Plikoyto BD, Broome CV. Epidemiology and preven- tion of meningococeal disease. Pediatr Infect Dis J. 1995; 14:643.

https://doi.org/10.1097/00006454-199508000-00001

18. Alhan E, Bozdemir N, Yüksel B, et al. Epidemiology of meningococcal infections in children in mid-southern part of Turkey. Eur J Epidemiol. 1995;11(4):393-6. https://doi.org/10.1007/BF01721223

19. Charles GP, Nivedita SS, Roshni M. The Nervous System Disorders. In: Kliegman RM, Behrman RE, Stanton BF, Schor NF, editors. Nelson textbook of pediatrics. 20th ed. Philadelphia: Elsevier Saunders; 2016. p. 2940.

20. Diederik VB, Jan G, Peter $\mathrm{Mcl}$, et al. Corticosteroids for acute bacterial meningitis. The Cochrane Collaboration 2009;1:1-2.

21. Prasad K, Singh MB. Corticosteroids for managing tuberculous meningitis. The Cochrane Collaboration 2009;1:10. https://doi.org/10.1002/14651858.CD002244.pub3

22. Taşkesen M, Taş MA. Çocuklarda merkezi sinir sistemi enfeksiyonları. Dicle Tıp Dergisi 2007;34:123-6.

23. Singal $M$, Skippen $P$, Isaacs $D$. Commentaries on fluid therapy for acute bacterial meningitis evidence-based child health: A Cochrane Review Journal 2009;4(1):61-4. https://doi.org/10.1002/ebch.304

24. Santos LC, Simões J, Severo M, et al. Bacterial meningitis in an urban area: etiologic study and prognostic factors. Infection 2007;35(6):406-13. https://doi.org/10.1007/s15010-007-7035-6

25. Pong A, Bradley JS. Bacterial meningitis and the newborn infant. Infect Dis Clin North Am. 1999;13(3):711-33. https://doi.org/10.1016/S0891-5520(05)70102-1

26. Abuhandan $\mathrm{M}$, Calık M, Oymak $\mathrm{Y}$, ve ark. Cocuklarda menenjit: 92 olgunun değerlendirilmesi. Dicle Tıp Dergisi 2013;40(1): 15-20. https://doi.org/10.5798/diclemedj.0921.2013.01.0217

27. Wasier AP, Chevret L, Essouri S, et al. Pneumococcal meningitis in a pediatric intensive care unit: Prognostic factors in a series of 49 children. Pediatr Crit Care Med. 2005;6(5):56872. https://doi.org/10.1097/01.PCC.0000170611.85012.01 